\title{
CEsifo \\ WORKING

\section{Domestic and Global Output Gaps as Inflation Drivers: What Does the Phillips Curve Tell?}

Martina Jašová, Richhild Moessner, Elöd Takáts 


\section{Impressum:}

CESifo Working Papers

ISSN 2364-1428 (electronic version)

Publisher and distributor: Munich Society for the Promotion of Economic Research - CESifo $\mathrm{GmbH}$

The international platform of Ludwigs-Maximilians University's Center for Economic Studies and the ifo Institute

Poschingerstr. 5, 81679 Munich, Germany

Telephone +49 (o)89 2180-2740, Telefax +49 (o)89 2180-17845, email office@cesifo.de

Editors: Clemens Fuest, Oliver Falck, Jasmin Gröschl

www.cesifo-group.org/wp

An electronic version of the paper may be downloaded

- from the SSRN website: $\quad$ www.SSRN.com

- from the RePEc website: $\quad$ www.RePEc.org

- from the CESifo website: www.CESifo-group.org/wp 


\title{
Domestic and Global Output Gaps as Inflation Drivers: What Does the Phillips Curve Tell?
}

\begin{abstract}
We study how domestic and global output gaps affect CPI inflation. We use a New-Keynesian Phillips curve framework which controls for nonlinear exchange rate movements for a panel of 26 advanced and 22 emerging economies covering the 1994Q1-2017Q4 period. We find broadly that both global and domestic output gaps are significant drivers of inflation both in the precrisis (1994-2008) and post-crisis (2008-2017) periods. Furthermore, after the crisis, in advanced economies the effect of the domestic output gap declines, while in emerging economies the effect of the global output gap declines. The paper demonstrates the usefulness of the New Keynesian Phillips curve in identifying the impact of global and domestic output gaps on inflation.
\end{abstract}

JEL-Codes: E310, E580, F620.

Keywords: output gaps, global factors, inflation.

\author{
Martina Jašová \\ Barnard College \\ Columbia University \\ USA - New York, NY 10027 \\ mjasova@barnard.edu
}

\author{
Richhild Moessner \\ Bank for International Settlements \\ Monetary \& Economic Department \\ Switzerland - 4002 Basel \\ richhild.moessner@bis.org
}

\author{
Elöd Takáts \\ Bank for International Settlements \\ Monetary \& Economic Department \\ Switzerland - 4002 Basel \\ elod.takats@bis.org
}

September 2018

We would like to thank Paul Beaudry, Francesco Zanetti and participants at a seminar at the Bank for International Settlements for useful comments and discussions. The views expressed are those of the authors and do not necessarily reflect those of the BIS. 


\section{Introduction}

Globalisation has changed the world, and in the process it may have changed how inflation works. Evidence, mostly from advanced economies, accumulates suggesting that global factors increasingly drive inflation and that domestic factors weaken. ${ }^{5}$ If so, that would leave little leverage for central banks to affect domestic inflation and thereby weaken their ability to achieve price stability. Hence, it is critical to understand the changes globalisation brought to the inflation process: To which degree do domestic versus global factors, such as output gaps, drive inflation? How has the role of these output gaps evolved after the financial crisis? And to which degree does the inflation process differ between advanced economies and less well-studied emerging markets?

We answer these questions in a modified New Keynesian Phillips curve framework. The dynamic panel framework, which develops further the analytic setup of Jašová, Moessner and Takáts (2018), allows us to answer the questions in a form directly interpretable for monetary policy while controlling for non-linear effects of exchange rate passthrough. The latter is particularly important for emerging markets. The setup also allows answering these questions without relying on a particular theoretical model (Forbes, 2018), and follows in spirit several papers using the Phillips curve setup (Blanchard, Cerutti, and Summers, 2015; Blanchard, 2016; and Mojon and Ragot, 2018). Furthermore, the panel setup allows us to exploit cross-country variation to uncover emerging trends early for a large group of countries - addressing the identification difficulties stemming from individual country level estimates highlighted recently by Forbes (2018) and Reichlin (2018).

We find broadly that both domestic and global output gaps matter: (i) across regions (advanced and emerging economies), and (ii) across time (before and after the financial crisis.) We observe the expected sign whenever the coefficient estimates are significant: positive output gaps are associated with higher inflation and negative output gaps with lower inflation.

However, we find suggestive evidence for very different trends between advanced and emerging markets after the global financial

\footnotetext{
The evidence on global factors started to accumulate well before the current policy debate and before the financial crisis, see for instance, Gamber and Hung (2001), Ball (2006), Bean (2006), Borio and Filardo (2007). After the financial crisis, a new stream of literature raised this question, in part responding to the unexpectedly weak response of inflation to the business cycle, see, for instance, Ciccarelli and Mojon (2010), Ihrig et al. (2010), Eickmeier and Pijnenburg (2013), Berganza et al. (2016), Mikolajun and Lodge (2016), Auer et al. (2017) and Forbes (2018).
} 
crisis: While in advanced economies the effect of the domestic output gap declines, in emerging markets the effect of the global output gap declines. Conversely, we find some signs that the effect of the global output gap remains broadly stable in advanced economies after the crisis, and the effect of the domestic output gap remains broadly stable in emerging markets (although the latter two results are less robust to different specifications).

We estimate the effects of output gaps using a New-Keynesian Phillips curve framework, for a panel of 26 advanced and 22 emerging economies for the 1994Q1-2017Q4 period using quarterly data. Acknowledging the potential differences in inflation processes, including, for instance, in inflation persistence or in exchange rate passthrough, we estimate the output gap effects separately for advanced and emerging economies.

Importantly, our setup allows for non-linear effects of exchange rate changes, which have been shown to be of particular importance for emerging markets (Jašová, Moessner and Takáts, 2018) as the underlying pass-through process may be non-linear (Bussière, 2013; Cheikh and Rault, 2015).

We also address the potential econometric issue created by the strong correlation between the domestic and global output gaps. To this end, we calculate the component of the domestic output gap for each country which is orthogonal to the global output gap - and repeat our analysis with this "orthogonal" domestic output gap. This approach effectively puts a lower bound on the estimates of the domestic output gap effect, ie it attributes all possible inflationary changes to the global output gap whenever the global and domestic output gaps are correlated. Still, even under this restrictive estimation approach we find the domestic output gap to be broadly significant along the lines of our benchmark results.

Turning to our detailed results, we show relevant differences between advanced economies and emerging markets. For advanced economies, both the global output gap and the domestic output gap generally affect inflation positively and significantly. This is true for the whole sample period of 1994-2017, in the pre-crisis period from 1994Q1 to 2008Q2, and in the post-crisis period from 2008Q3 to end2017 (except that the global output gap is significant pre-crisis only when using the orthogonal domestic output gap specification, not when using the benchmark domestic output gap specification). We find a significant decrease in the domestic output gap coefficient post-crisis for advanced economies. When restricting the post-crisis period to 2009Q3-2017Q4, the estimated domestic output gap coefficient 
becomes insignificant for advanced economies. We find that the effect of the global output gap remains broadly stable in advanced economies after the crisis.

For emerging economies, we find that the global output gap affects inflation positively and significantly. Again this is true for the whole sample period of 1994-2017, in the pre-crisis period from 1994 to 2008Q2, and in the post-crisis period from 2008Q3 to end-2017. By contrast, the domestic output gap has a significant effect on inflation in the post-crisis period from 2008Q3 to end-2017, but not in the precrisis period. This significance survives if we restrict the post-crisis period to the 2009Q3-2017Q4 period, but then the global output gap becomes insignificant. However, the pre-crisis insignificance of the domestic output gap arises due to large standard errors reflecting various emerging market crises in the 1990s: re-running the analysis for the 2000Q1-2008Q2 period yields a significant domestic output gap coefficient. We do not find a significant change in the domestic output gap coefficient for emerging markets post-crisis. The global output gap becomes a less important inflation driver in the post-crisis period for emerging economies when excluding the quarters of the financial crisis, but not when including them.

We subject our benchmark results to extensive robustness checks. While our benchmark specification uses dynamic system GMM estimation, we show that our results are robust to applying a withingroup estimation. Second, we also saturate the specification with time fixed effects to absorb all observed and unobserved global factors and we find that this does not materially affect our domestic output gap estimates. Finally, we test for robustness to using a different measure of the global output gap estimated by economists at the World Bank.

Our paper contributes to the literature in three main areas. First, we expand the standard domestic New Keynesian Phillips curve by adding global output gaps and non-linear exchange rate pass-through. This provides a robust analytical framework to assess changes both in advanced and emerging markets - and demonstrates the usefulness of the (modified) New Keynesian Phillips curve in an international setting along the lines of recent work in Blanchard, Cerutti, and Summers (2015), Blanchard (2016) and Forbes (2018). Our results on the global output gap confirm the findings in Forbes (2018) who finds, using a Phillips curve framework for 31 advanced and 12 emerging economies, that global factors can significantly affect inflation, and that including more comprehensive controls for global factors can meaningfully improve the ability of simple models to predict inflation. Our results are also consistent with Mojon and Ragot (2018) who find strong support 
for the wage Phillips curve for the G7 countries, eight euro area member countries and 19 OECD countries.

Second, we uncover different trends in advanced and emerging economies after the financial crisis: While the effect of the domestic output gap declines in advanced economies, the effect of the global output gap declines in emerging markets. These findings are new, because, as we review below, most of the literature either focused on advanced economies or on global trends, but did not separate advanced and emerging economy trends.

Our advanced economy findings on the Phillips curve flattening are consistent with a fast-growing literature, though our evidence on the post-crisis flattening are potentially new. Blanchard (2016) shows that the slope of the US Phillips curve (in terms of unemployment) has substantially declined. However, he dates the decline dating back to the 1980 s rather than to the global financial crisis and finds no evidence of a further decline after the crisis. Similarly, Blanchard et al. (2015) estimate a Phillips curve relationship over the past 50 years for 20 advanced economies, and find that the effect of unemployment on inflation decreased until the early 1990s, but has remained roughly stable since then. Ball and Mazumder (2011) find that the Phillips curve has flattened since the mid-1980s, and that the backward-looking Phillips curve estimated over 1985-2007 continues to fit after 2007 applied to median CPI inflation. Gordon (2013) reports that a Phillips curve which allows for a time-varying NAIRU can explain the behaviour of both headline and core US inflation (based on the deflator for Personal Consumption Expenditures) over the five decades to 2013. Kuttner and Robinson (2010) show evidence of a flattening structural new-Keynesian Phillips curve for the United States and Australia. Using a simple reduced-form Phillips curve, Roberts (2006) finds evidence of a flattening Phillips curve for the United States, and concludes that changes in monetary policy can account for most or all of the flattening (with Kohn (2005) following a similar argument). Borio and Filardo (2007) argue that the role of global factors in affecting inflation has grown especially since the 1990s, and that for some economies global factors appear to have supplanted the role of domestic measures of economic slack. Ciccarelli and Mojon (2010) argue that inflation in industrialised countries is largely a global phenomenon, with a common factor accounting for nearly $70 \%$ of the variance of national inflation rates, and that there is an error correction mechanism that brings national inflation rates back to global inflation. Auer, Borio and Filardo (2017) find that the expansion of global value chains, ie crossborder trade in intermediate goods and services, is an important 
channel through which global economic slack influences domestic inflation.

Our emerging market evidence is new, as most of the literature has focused on advanced economies. Most recently Forbes (2018) uses a sample of 31 advanced and 12 emerging economies, but the analysis only restricts to the global trends and does not separate the trends between advanced and emerging economies.

Third, to the best of our knowledge this is the first paper that explicitly addressed the issue of multicollinearity across global and domestic output gaps. To this end, we introduce orthogonal output gap estimations that use the component of the domestic output gap which is orthogonal to the global output gap when estimating a NewKeynesian Phillips curve. This allows us to disentangle the impact of strictly and purely domestic factors.

One caveat to our results is that they apply to groups of countries, and not necessarily to individual economies. Hence, our results do not offer direct implications for individual countries and they should be seen rather as broader trends across advanced economies and emerging markets.

The remainder of the paper is organised as follows. Section 2 introduces the data. Section 3 presents the benchmark specification and results. Section 4 discussed the evolution of the output gap effects and Section 5 presents results using orthogonal domestic output gaps. Section 6 provides robustness results. Finally, the section 7 concludes.

\section{Data}

We analyse quarterly time-series data for 22 emerging $^{6}$ and 26 advanced $^{7}$ economies over the period 1994Q1-2017Q4. We study the effect of domestic and global output gaps on consumer price inflation, using log differences in quarterly seasonally adjusted consumer price indices (CPI) as our dependent variable.

We control for the effects of exchange rate changes on inflation. We use the BIS nominal effective exchange rate (NEER) broad indices available from 1994 onwards with 2010 as the indices' base year. In the

6 Argentina, Brazil, Chile, China, Colombia, the Czech Republic, Hong Kong SAR, Hungary, India, Indonesia, Israel, Korea, Mexico, Malaysia, Peru, the Philippines, Poland, Russia, Singapore, South Africa, Thailand and Turkey.

7 Australia, Canada, Denmark, Japan, New Zealand, Norway, Sweden, Switzerland, the United Kingdom, the United States, Austria, Belgium, Estonia, Finland, France, Germany, Greece, Ireland, Italy, Latvia, Lithuania, the Netherlands, Portugal, Slovak Republic, Slovenia and Spain. 
regression analysis, we use log differences in the average quarterly NEER indices. In our definition, an increase in the NEER implies an appreciation of the local exchange rate.

Our measure of the domestic output gap is calculated by employing the standard univariate Hodrick-Prescott filtering method for each country in our sample individually. We use the standard smoothing parameter $\lambda$ set to 1600 for all available quarterly GDP data. We also use growth projections to address the endpoint problem in the estimation. The underlying real GDP series are taken from national sources. We use the data starting in 1994Q1 or later depending on their availability. ${ }^{8}$ The global output gap is calculated according to the same methodology as the domestic output gap, and it is computed from national data as a weighted average. We use GDP on a PPP basis as weights for the calculation of the global output gap.

For robustness tests, we also use global output gap estimates from Kose, Ohnsorge and Some (2018), economists at the World Bank. ${ }^{9}$ They estimated national output gaps of each country using nine different methods (including univariate and multivariate filters, the production function approach and two expectations-based measures), and then aggregated them into a global output gap using GDP weights, for a sample including 15 advanced economies and 23 emerging market and developing economies, for quarterly data from 2000-2017.

We control for oil prices, using average quarterly West Texas Intermediate (WTI) crude oil spot prices in US dollars transformed into quarterly log changes. We also include inflation expectations within the New-Keynesian Phillips curve setup. We take end-year inflation expectations data from Consensus Economics and interpolate it to quarterly frequency. In detail, we do so as follows: For Q4, we take the end-year expectations data. For Q1, we linearly interpolate the current year's end-year expectations. For Q2, we use the current end-year estimates and deduct the effect of the actual quarterly inflation realisation for Q1. For Q3, following the same logic, we use the current end-year estimates and deduct the effect of the actual quarterly inflation realisations for Q1 and Q2.

Appendix A provides a detailed description of the data.

8 Data are available since 1995 Q1 for Hungary, Israel and Poland; since 1996 Q1 for Chile and the Czech Republic; since 1996 Q2 for India and since 1998 Q1 for the Philippines.

9 We would like to thank Ayhan Kose and Franziska Ohnsorge for providing us with a quarterly time series of their global output gap estimates. 


\section{Benchmark specification and results}

\section{Empirical strategy}

We estimate the effects of domestic and global output gaps on inflation from the panel regression described by equation (1), our benchmark regression:

$$
\begin{aligned}
\pi_{\mathrm{it}}=\alpha_{\mathrm{i}}+\rho \mathrm{E}_{\mathrm{t}} \pi_{\mathrm{it}+1}+\delta \pi_{\mathrm{it}-1}+\phi \mathrm{y}_{\mathrm{it}}^{d}+\lambda \mathrm{y}_{\mathrm{t}}^{g}+\theta \pi_{\mathrm{t}}^{\mathrm{oil}} \\
-\sum_{\mathrm{j}=0}^{3} \gamma_{\mathrm{j}} \Delta \mathrm{NEER}_{\mathrm{it}-\mathrm{j}} \\
-\sum_{\mathrm{k}=0}^{3} \mu_{\mathrm{k}} \Delta \mathrm{NEER}_{\mathrm{it}-\mathrm{k}}^{2}-\sum_{\mathrm{l}=0}^{3} v_{\mathrm{l}} \Delta \mathrm{NEER}_{\mathrm{it}-\mathrm{l}}^{3}+\varepsilon_{\mathrm{it}}
\end{aligned}
$$

Here, $\pi_{i t}$ denotes log differences in quarterly seasonally adjusted consumer price indices (CPI) in country $i$ in quarter $t ; \mathrm{E}_{\mathrm{t}} \pi_{\mathrm{it}+1}$ denotes quarter-on-quarter inflation expectations; $\mathrm{y}_{\mathrm{t}}^{g}$ is the global output gap; $\mathrm{y}_{\mathrm{it}}^{d}$ is the domestic output gap in country $i$ in quarter $t, \triangle N E E R_{i t}$ is the (change in the log of) the nominal effective exchange rate; and $\pi_{t}^{\text {oil }}$ denotes log-differences in oil prices.

The estimation period is 1994Q1-2017Q4. To capture any nonlinearities in the exchange rate pass-through, we extend the specification to include quadratic and cubic changes in exchange rates $\left(\triangle \mathrm{NEER}_{\mathrm{it}}^{2}\right.$ and $\triangle \mathrm{NEER}_{\mathrm{it}}^{2}$ respectively). All exchange rate terms are presented with a negative sign given that in the original series local exchange rate depreciation is reflected as a decrease in the NEER. The specification uses contemporaneous exchange rate change and three additional lags to capture exchange rate pass-through over the period of one year. We also include country fixed effects $\left(\alpha_{\mathrm{i}}\right)$ to control for any observed or unobserved time-invariant country heterogeneity. We estimate equation (1) separately for advanced and emerging economies.

We use the system generalized method of moments (GMM) following Arellano and Bover (1995) and Blundell and Bond (1998) in order to deal with panel data with endogenous explanatory variables. It is also appropriate to use this method here since the coefficient on the lagged dependent variable, lagged inflation, is significant for both advanced and emerging economies. The benchmark specification relies on the system GMM technique with 2-8 lags of log NEER changes, of 
the domestic output gap, and of lags of log CPI changes as GMM instruments for levels and first differences equations.

\section{Results}

We estimate our benchmark regression (1) separately for advanced and emerging economies (Tables 1 and 2, respectively). We show the main coefficient estimates for both groups for four time periods: (1) for the full sample period (1994Q1-2017Q4); (2) for the pre-crisis period (1994Q1-2008Q2); (3) for the post-crisis period including the crisis quarters (2008Q3-2017Q4); and (4) for the post-crisis period excluding the crisis quarters (2009Q3-2017Q4). In addition, for emerging markets we also show the estimates for the pre-crisis periods which excludes the emerging markets crises in the 1990s (2000Q1-2008Q2).

\begin{tabular}{|c|c|c|c|c|}
\hline \multirow{2}{*}{\multicolumn{5}{|c|}{$\begin{array}{l}\text { Effect of domestic and global output gaps for advanced economies } \\
\text { Coefficients using system GMM estimations in Equation } 1\end{array}$}} \\
\hline & & & & \\
\hline & \multicolumn{4}{|c|}{ Dependent variable: $\pi_{i t}$} \\
\hline & $\begin{array}{c}\text { Whole period } \\
\text { 1994Q1-2017Q4 }\end{array}$ & $\begin{array}{c}\text { Pre-crisis } \\
\text { 1994Q1-2008Q2 }\end{array}$ & $\begin{array}{c}\text { Post-crisis 1 } \\
\text { 2008Q3-2017Q4 }\end{array}$ & $\begin{array}{c}\text { Post-crisis 2 } \\
\text { 2009Q3-2017Q4 }\end{array}$ \\
\hline & (1) & (2) & (3) & (4) \\
\hline \multirow{2}{*}{$y_{i t}^{d}$} & $0.0370^{* * *}$ & $0.0556^{* * *}$ & $0.0217^{* *}$ & 0.00971 \\
\hline & $(0.00988)$ & $(0.0140)$ & $(0.0100)$ & $(0.0114)$ \\
\hline \multirow{2}{*}{$y_{t}^{g}$} & $0.0316^{* *}$ & -0.00432 & $0.0492 * *$ & $0.114^{* *}$ \\
\hline & $(0.0149)$ & $(0.0196)$ & $(0.0219)$ & $(0.0461)$ \\
\hline \multirow[t]{2}{*}{$\mathrm{E}_{\mathrm{t}} \pi_{\mathrm{it}+1}$} & 0.0737 & $0.118^{* *}$ & $-0.0531 *$ & $-0.0761^{*}$ \\
\hline & $(0.0448)$ & $(0.0449)$ & $(0.0306)$ & $(0.0431)$ \\
\hline \multirow[t]{2}{*}{$\pi_{\mathrm{it}-1}$} & $0.507 * * *$ & $0.486^{* * *}$ & $0.481 * * *$ & $0.440^{* * *}$ \\
\hline & $(0.0468)$ & $(0.0598)$ & $(0.0351)$ & $(0.0421)$ \\
\hline \multirow[t]{2}{*}{$\pi_{t}^{\text {oil }}$} & $0.0118^{* * *}$ & $0.0117 * * *$ & $0.0108^{* * *}$ & $0.0129^{* * *}$ \\
\hline & $(0.00074)$ & $(0.0017)$ & $(0.0008)$ & $(0.0011)$ \\
\hline NEER terms ${ }^{\mathrm{a}}$ & Yes & Yes & Yes & Yes \\
\hline Country FE & Yes & Yes & Yes & Yes \\
\hline Number of countries & 26 & 26 & 26 & 26 \\
\hline Number of observations & 2,291 & 1,329 & 962 & 858 \\
\hline Sargan test ${ }^{\mathrm{b}}$ & 1 & 0.998 & 0.890 & 0.250 \\
\hline Hansen test ${ }^{\mathrm{b}}$ & 1 & 1 & 1 & 1 \\
\hline Serial correlation test ${ }^{\mathrm{d}}$ & 0.156 & 0.184 & 0.147 & 0.0466 \\
\hline $\begin{array}{l}\text { Note: System GMM estima } \\
* * * p<0.01, * * p<0.05, * p\end{array}$ & and Bover (1995) & ll and Bond (1998 & anel estimator. Rol & $\mathrm{d}$ errors in parentheses. \\
\hline
\end{tabular}

For advanced economies, we find that the global output gap affects inflation positively and significantly in most time periods (Table 1). This is the case in the whole sample period of 1994-2017 (Column 1), and in both post-crisis periods (Columns 3 and 4). Yet, we do not find any significant global output gap effect for the pre-crisis period in this benchmark specification (Column 2). But as shown below, the global 
output gap effect is significant also in the pre-crisis period when using the orthogonal domestic output gap specification (see Table 5). Overall, whenever statistically significant, the coefficient on the global output gap is larger than the coefficient on the domestic output gap.

The statistical tests for over-identifying restrictions confirm that our specification is appropriate (bottom rows of Table 1). We consistently perform these tests throughout our analysis: while they confirm our setup in all specifications, we do not discuss them explicitly later on.

The domestic output gap estimates for advanced economies decline later in our sample period. The coefficient estimates are significant and large in the pre-crisis period (Column 2), but they are already smaller in the post-crisis period (2008Q3-2017Q4, Column 3) and become outright statistically insignificant when we exclude the crisis quarters (2009Q3-2017Q4, Column 4). While insignificance might arise due to smaller sample size, we do not observe a similar issue with the global output gap, which remains significant in that period. These findings suggest that the effect of the domestic output gap has declined in advanced economies. These results contribute evidence to recent discussions on a possible flattening of the (domestic) Phillips curve (Cunliffe, 2017; IMF, 2013; Blanchard et al., 2015; Blanchard, 2016; Kiley, 2015).

For emerging markets, the global output gap affects inflation positively and significantly in all time periods, except in the post-crisis period which excludes the financial crisis quarters (see Table 2). Furthermore, the global output gap coefficients reported in Columns 1-4 are consistently larger than the ones on the domestic output gap. Interestingly, the effect of the global output gap in emerging markets shows a similar pattern as that of the domestic output gap in advanced economies, ie it declines after the financial crisis.

The domestic output gap affects inflation in emerging economies both before and after the financial crisis. At first sight it appears that the domestic output gap affects inflation only after the financial crisis (Columns 4 and 5), but not in the pre-crisis period (Column 2). However, this pre-crisis insignificance of the domestic output gap coefficient seems to arise due to large standard errors reflecting various emerging market crises in the 1990s. Re-running the analysis for the 2000Q1-2008Q2 period yields a significant domestic output gap coefficient (Column 3). This suggests that the domestic output gap was an important inflation driver also in the pre-crisis period for emerging markets (though perhaps not in the volatile period of 1990s). In sum, the emerging-market-specific estimates do not suggest a flattening of the domestic Phillips curve. This is in contrast to the results observed 
for advanced economies and highlights the value to undertake this analysis separately for emerging markets.

\begin{tabular}{|c|c|c|c|c|c|}
\hline \multirow{2}{*}{\multicolumn{6}{|c|}{$\begin{array}{l}\text { Effect of domestic and global output gaps for emerging markets } \\
\text { Coefficients using system GMM estimations in Equation } 1\end{array}$}} \\
\hline & & & & & \\
\hline & \multicolumn{5}{|c|}{ Dependent variable: $\pi_{i t}$} \\
\hline & $\begin{array}{c}\text { Whole period } \\
\text { 1994Q1-2017Q4 } \\
\text { (1) }\end{array}$ & $\begin{array}{c}\text { Pre-crisis 1 } \\
\text { 1994Q1-2008Q2 } \\
\text { (2) }\end{array}$ & $\begin{array}{c}\text { Pre-crisis } 2 \\
\text { 2000Q1-2008Q2 } \\
\text { (3) }\end{array}$ & $\begin{array}{c}\text { Post-crisis 1 } \\
\text { 2008Q3- } \\
\text { 2017Q4 } \\
\text { (4) }\end{array}$ & $\begin{array}{c}\text { Post-crisis } 2 \\
\text { 2009Q3-2017Q4 } \\
\text { (5) }\end{array}$ \\
\hline \multirow[t]{2}{*}{$\mathrm{y}_{\mathrm{it}}^{d}$} & 0.0335 & 0.0295 & $0.0502^{* *}$ & $0.0333^{*}$ & $0.0399^{* *}$ \\
\hline & $(0.0215)$ & $(0.0303)$ & $(0.0190)$ & $(0.0173)$ & $(0.0188)$ \\
\hline \multirow{2}{*}{$\mathrm{y}_{\mathrm{t}}^{g}$} & $0.0729 *$ & $0.128^{* * *}$ & $0.120^{* *}$ & $0.0845^{* *}$ & -0.0278 \\
\hline & $(0.0373)$ & $(0.0432)$ & $(0.0429)$ & $(0.0382)$ & $(0.0361)$ \\
\hline \multirow[t]{2}{*}{$\mathrm{E}_{\mathrm{t}} \pi_{\mathrm{it}+1}$} & $0.168^{* * *}$ & $0.158^{* * *}$ & $0.170^{* * *}$ & $0.267^{* * *}$ & $0.314 * * *$ \\
\hline & $(0.0299)$ & $(0.0376)$ & $(0.0265)$ & $(0.0670)$ & $(0.0522)$ \\
\hline \multirow[t]{2}{*}{$\pi_{\mathrm{it}-1}$} & $0.624^{* * *}$ & $0.614^{* * *}$ & $0.450 * * *$ & $0.475^{* * *}$ & $0.451^{* * *}$ \\
\hline & $(0.0293)$ & $(0.0443)$ & $(0.0954)$ & $(0.0324)$ & $(0.0312)$ \\
\hline \multirow[t]{2}{*}{$\pi_{\mathrm{t}}^{\mathrm{oil}}$} & $0.0113^{* * *}$ & 0.00263 & $0.0100 * * *$ & $0.0149 * * *$ & $0.00907^{* * *}$ \\
\hline & $(0.00222)$ & $(0.00405)$ & $(0.00333)$ & $(0.00231)$ & $(0.00215)$ \\
\hline NEER terms $^{a}$ & Yes & Yes & Yes & Yes & Yes \\
\hline Country FE & Yes & Yes & Yes & Yes & Yes \\
\hline Number of countries & 22 & 22 & 22 & 22 & 22 \\
\hline Number of observations & 1,977 & 1,163 & 748 & 814 & 726 \\
\hline Sargan test ${ }^{\mathrm{b}}$ & 1 & 0.995 & 1 & 0.976 & 0.995 \\
\hline Hansen test ${ }^{\mathrm{b}}$ & 1 & 1 & 1 & 1 & 1 \\
\hline Serial correlation test ${ }^{\mathrm{d}}$ & 0.398 & 0.390 & 0.230 & 0.473 & 0.262 \\
\hline \multicolumn{6}{|c|}{$\begin{array}{l}\text { Note: System GMM estimation using Arellano and Bover (1995) and Blundell and Bond (1998) dynamic panel estimator. Robust standard errors in parentheses } \\
* * * \mathrm{p}<0.01,{ }^{* *} \mathrm{p}<0.05, * \mathrm{p}<0.1 \text {. }\end{array}$} \\
\hline
\end{tabular}

One caveat arises, however, in interpreting the above results: the panel setup that we use implies that our results apply only to groups of countries, and not to individual economies. Hence, the above trends should not be read as specific estimates for any country in our sample: it is not inconceivable that some advanced or emerging economies exhibit very different dynamics than what we observe for the group.

Taken together, the results suggest that the New-Keynesian Phillips curve framework continues to be useful for estimating the effects of output gaps on inflation in a cross-country setting. It also suggests that after the financial crisis the effect of the domestic output gap on inflation weakened in advanced economies, while the effect of the global output gap weakened in emerging markets. In the following section, we analyse these potential trends more formally. 


\section{Evolution of the output gap effects}

Our benchmark results suggested that the effect of output gaps on inflation has changed after the financial crisis: On the one hand, in advanced economies we saw a decline of the domestic output gap coefficient consistent with a flattening of the domestic Phillips curve. On the other hand, in emerging economies we saw the effect of the global output gap decline. To investigate these suggestive trends more formally, we formally evaluate the statistical significance of post-crisis change in this section for our full sample.

Formally, we re-estimate equation (1) by adding an interaction dummy for the post-crisis years, as shown in equation (2):

$$
\begin{aligned}
\pi_{\mathrm{it}}= & \alpha_{\mathrm{i}}+\rho \mathrm{E}_{\mathrm{t}} \pi_{\mathrm{it}+1}+\rho^{\prime} \text { Post }_{t} \mathrm{E}_{\mathrm{t}} \pi_{\mathrm{it}+1}+\delta \pi_{\mathrm{it}-1}+\delta^{\prime} \text { Post }_{t} \pi_{\mathrm{it}-1}+ \\
& \phi \mathrm{y}_{\mathrm{it}}^{d}+\phi^{\prime} \text { Post }_{t} \mathrm{y}_{\mathrm{it}}^{d}+\lambda \mathrm{y}_{\mathrm{t}}^{g}+\lambda^{\prime} \text { Post }_{t} \mathrm{y}_{\mathrm{t}}^{g}+\theta \pi_{\mathrm{t}}^{\text {oil }}+\theta^{\prime} \text { Post }_{t} \pi_{\mathrm{t}}^{\text {oil }}- \\
& \sum_{\mathrm{j}=0}^{3} \gamma_{\mathrm{j}} \Delta \mathrm{NEER}_{\mathrm{it}-\mathrm{j}}-\sum_{\mathrm{j}=0}^{3} \gamma_{\mathrm{j}}^{\prime} \text { Post }_{t} \Delta \mathrm{NEER}_{\mathrm{it}-\mathrm{j}}- \\
& \sum_{\mathrm{k}=0}^{3} \mu_{\mathrm{k}} \Delta \mathrm{NEER}_{\mathrm{it}-\mathrm{k}}^{2}-\sum_{\mathrm{k}=0}^{3} \mu_{\mathrm{k}}^{\prime} \text { Post }_{t} \Delta \mathrm{NEER}_{\mathrm{it}-\mathrm{k}}^{2}- \\
& \sum_{\mathrm{l}=0}^{3} v_{\mathrm{l}} \Delta \mathrm{NEER}_{\mathrm{it}-\mathrm{l}}^{3}-\sum_{\mathrm{l}=0}^{3} v_{\mathrm{l}} \text { Post }_{t} \Delta \mathrm{NEER}_{\mathrm{it}-\mathrm{l}}^{3}+\varepsilon_{\mathrm{it}}
\end{aligned}
$$

When introducing these dummies denoted by Post $_{t}$, we consider both the case when the crisis quarters are included (2008Q3-2017Q4), and when they are excluded (2009Q3-2017Q4). This allows us to investigate whether the potential post-crisis flattening of the Phillips curve happened after the crisis or even during the crisis (and whether the dramatic output gap movements during the crisis might affect the estimates).

The results for advanced economies are shown in Table 3. The framework of including both pre- and both crisis periods, albeit with different coefficients, allows us to investigate whether the post-crisis change is statistically significant. We focus on the specifications where we allow, as in equation (2), simultaneous changes in all coefficient estimates. Column 1 uses a specification when the post-crisis period includes the crisis quarters, whereas Column 2 shows the results when the crisis quarters are excluded from the post-crisis estimates.

We find that, consistent with our benchmark results, the effect of the domestic output gap declines significantly in advanced economies irrespective of whether we include the crisis quarters or not. 
Furthermore, this result is also robust when we introduce interaction terms only for the output gap variables (results available upon request).

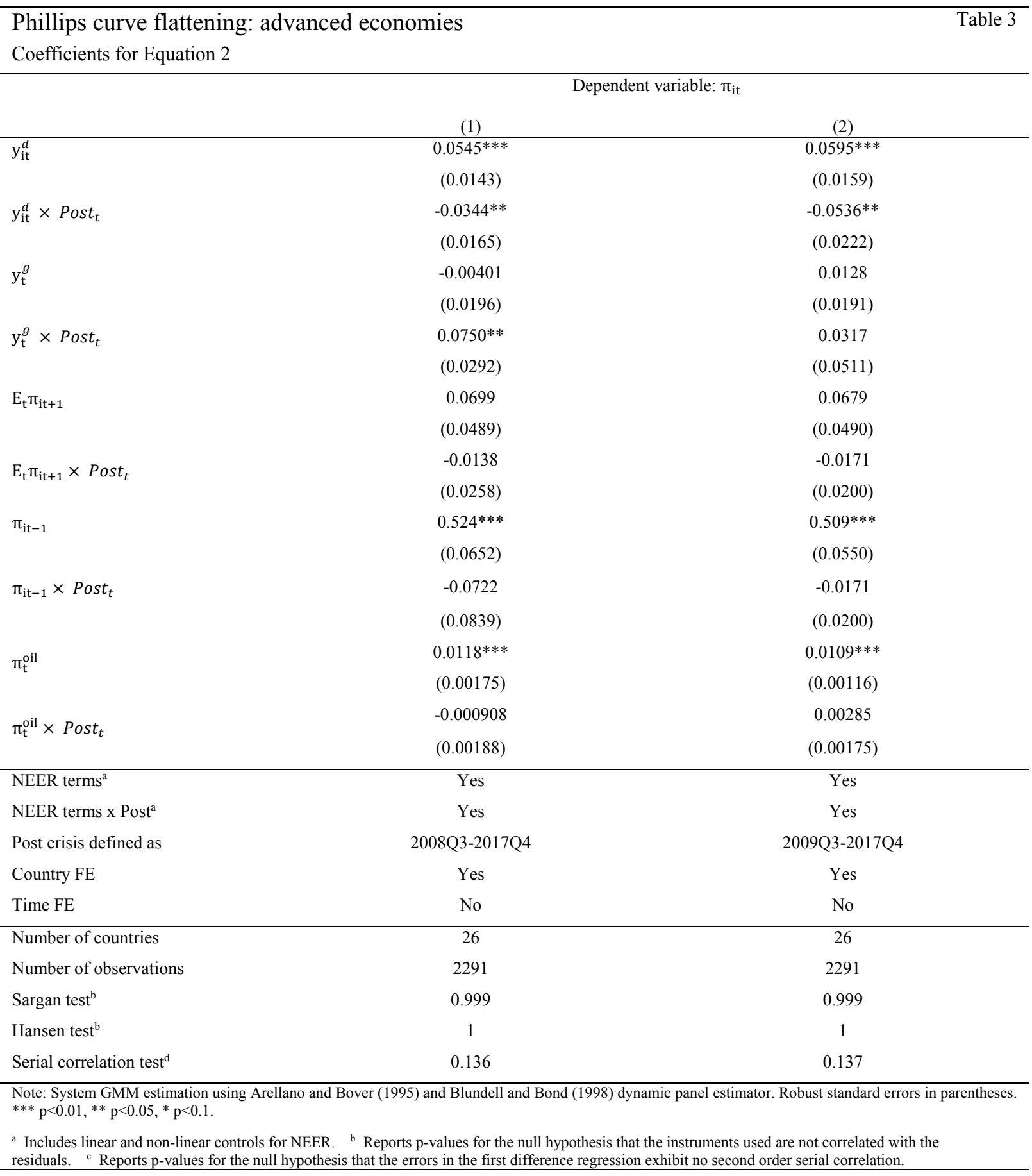

The decline is larger in the domestic gap coefficient estimates when we look at the period excluding the crisis quarters (Column 2). For the global output gap, the interaction coefficient is less consistent: while its effect increases significantly when including the financial crisis quarters (Column 1), the change becomes insignificant when we exclude the crisis, ie the quarters characterised by very strong correlations between the global and domestic output gaps (Column 2). 
For emerging economies, we repeat the estimation of equation (2) with both post-crisis dummies (Table 4). Consistent with our benchmark results, we do not find any significant change in the domestic output gap coefficient in any specifications. In contrast, we do find that the global output gap becomes a significantly less important inflation driver after the crisis when we exclude the crisis quarters (Column 1). This decline, however, becomes insignificant once we include the volatile quarters of the financial crisis (Column 2). Again, these results remain robust when we introduce interaction terms only for the output gap variables (results available upon request).

\begin{tabular}{|c|c|c|}
\hline $\begin{array}{l}\text { Phillips curve flatt } \\
\text { Coefficients for Equat }\end{array}$ & kets & Table 4 \\
\hline & & \\
\hline & (1) & (2) \\
\hline $\mathrm{y}_{\mathrm{it}}^{d}$ & 0.0291 & 0.0332 \\
\hline & $(0.0307)$ & $(0.0281)$ \\
\hline $\mathrm{y}_{\mathrm{it}}^{d} \times$ Post $_{t}$ & 0.0101 & -0.00148 \\
\hline & $(0.0405)$ & $(0.0412)$ \\
\hline $\mathrm{y}_{\mathrm{t}}^{g}$ & $0.131 * * *$ & $0.115^{* *}$ \\
\hline & $(0.0432)$ & $(0.0504)$ \\
\hline $\mathrm{y}_{\mathrm{t}}^{g} \times$ Post $_{t}$ & -0.0320 & $-0.178 * *$ \\
\hline & $(0.0529)$ & $(0.0674)$ \\
\hline$E_{t} \pi_{i t+1}$ & $0.154 * * *$ & $0.162 * * *$ \\
\hline & $(0.0376)$ & $(0.0354)$ \\
\hline $\mathrm{E}_{t} \pi_{i t+1} \times$ Post $_{t}$ & $0.0757^{* * *}$ & $0.0769^{* * *}$ \\
\hline$e_{t}$ & $(0.0150)$ & $(0.0136)$ \\
\hline$\pi_{\mathrm{it}-1}$ & $0.619^{* * *}$ & $0.618^{* * *}$ \\
\hline & $(0.0450)$ & $(0.0408)$ \\
\hline$\pi_{\mathrm{it}-1} \times$ Post $_{t}$ & $-0.271 * * *$ & $-0.274 * * *$ \\
\hline & $(0.0497)$ & $(0.0358)$ \\
\hline$\pi_{+}^{\text {oil }}$ & 0.00308 & $0.0116^{* * *}$ \\
\hline & $(0.00392)$ & $(0.00288)$ \\
\hline$\pi_{\mathrm{t}}^{\mathrm{oil}} \times$ Post $_{t}$ & 0.00308 & -0.00210 \\
\hline & $(0.00392)$ & $(0.00271)$ \\
\hline NEER terms ${ }^{\mathrm{a}}$ & Yes & Yes \\
\hline NEER terms $x$ Post $t^{\mathrm{a}}$ & Yes & Yes \\
\hline Post crisis defined as & 2008Q3-2017Q4 & 2009Q3-2017Q4 \\
\hline Country FE & Yes & Yes \\
\hline Time FE & No & No \\
\hline Number of countries & 22 & 22 \\
\hline Number of observations & 1,977 & 1,977 \\
\hline Sargan test $\mathrm{t}^{\mathrm{b}}$ & 1 & 1 \\
\hline Hansen test $\mathrm{t}^{\mathrm{b}}$ & 1 & 1 \\
\hline Serial correlation test ${ }^{\mathrm{d}}$ & 0.157 & 0.161 \\
\hline
\end{tabular}


To summarize, our results show that the Phillips curve relationship has changed significantly both for advanced and emerging market economies after the global financial crisis - though not in the same way. For advanced economies, we see a statistically significant decline in the estimated domestic output gap coefficient irrespective of how we define the post-crisis period. This result contributes evidence to the recent discussions on the possible flattening of the Phillips curve. In contrast, for emerging markets we find a statistically significant decline in the global output gap coefficient estimate after the financial crisis in the specification when we exclude the financial crisis years.

\section{Orthogonal domestic output gap}

In this section we examine more formally the potential implications of domestic and global output gap correlations, especially during the financial crisis. The strong correlation between the global and domestic output gaps (the correlation coefficient is 0.55 in the full sample), particularly during the financial crisis (the correlation coefficient is 0.75 between 2008Q3 and 2009Q2), could potentially confound the coefficient estimates. The evolution of the correlation between domestic and global output gaps for advanced and emerging economies is shown in Graph 1. For both advanced and emerging economies, the correlation between domestic and global output gaps tended to increase from the start of the sample period until the financial crisis, when it peaked and fell back subsequently. Furthermore, our regressions in the previous section hint at the possibility that the domestic and the global output gap can take over each other's effect as we include the crisis quarters.

To address this correlation, we orthogonalise the domestic output gap with respect to the global output gap. Specifically, we use the component of the domestic output gap in country $i$ in quarter $t$ which is orthogonal to the global output gap, instead of using the usual domestic output gap estimate directly. We call this measure the orthogonal domestic output gap, and denote it by $\mathrm{y}_{\mathrm{it}}^{d o}$. Note that by definition it is uncorrelated with the global output gap.

Formally, we estimate the orthogonal domestic output gap in two steps. In the first step, we regress the domestic output gap on the global output gap and a country fixed effect in fixed-effect (withingroup) panel regression, as shown in Equation 3: 


$$
\mathrm{y}_{\mathrm{it}}^{d}=\alpha_{\mathrm{i}}+\beta \mathrm{y}_{\mathrm{t}}^{g}+\varepsilon_{\mathrm{it}}
$$

We estimate equation (3) for advanced and emerging economies together in our main specification.

Correlation of global and domestic output gaps ${ }^{1}$

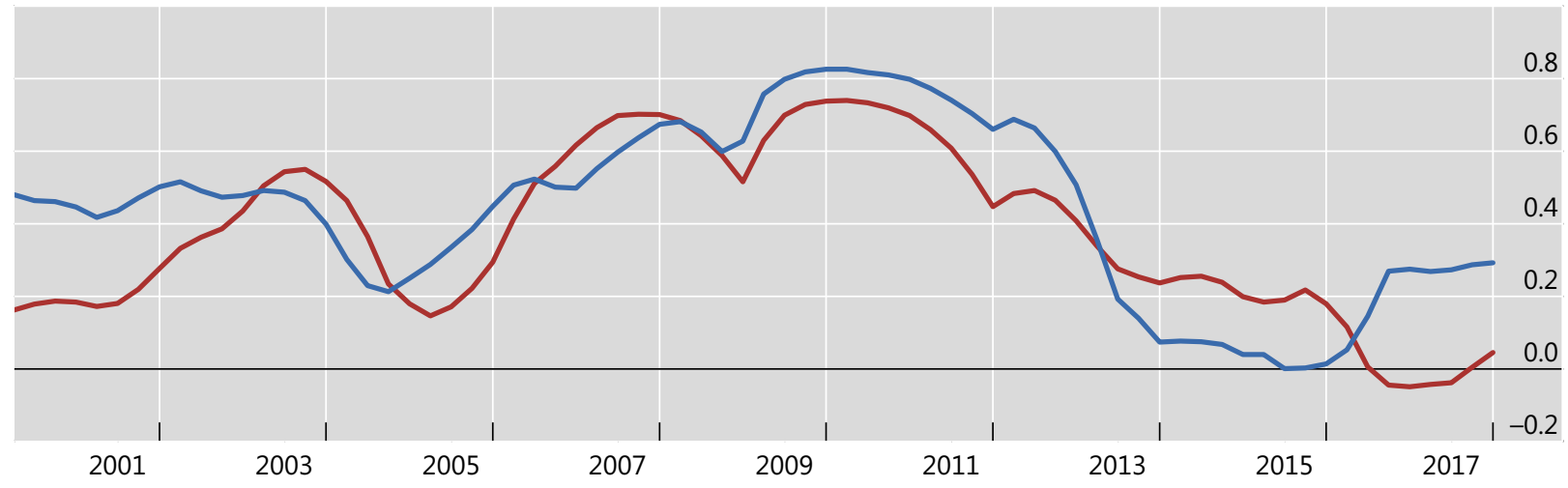

— Advanced economies _ Emerging market economies

1 Three-year rolling window estimates based on quarterly data. Output gaps calculated with standard Hodrick-Prescott filter applied to quarterly real GDP series (see Appendix Table A1).

Sources: National data, BIS, authors' calculations.

In the second step, we define the orthogonal domestic output gap as the combined residual, namely the sum of the fixed-error component, $\widetilde{\alpha_{i}}$, and of the overall error component, $\tilde{\varepsilon}_{i t}$ estimated in Equation 3, as shown in Equation 4:

$$
y_{i t}^{d o}=\widetilde{\alpha}_{i}+\tilde{\varepsilon}_{i t}
$$

We then re-estimate the main specification using the above orthogonal domestic out gap, instead of the domestic output gap, as shown in Equation 5:

$$
\begin{aligned}
\pi_{\mathrm{it}}= & \alpha_{\mathrm{i}}+\rho \mathrm{E}_{\mathrm{t}} \pi_{\mathrm{it}+1}+\delta \pi_{\mathrm{it}-1}+\phi \mathrm{y}_{\mathrm{it}}^{d o}+\lambda \mathrm{y}_{\mathrm{t}}^{g}+\theta \pi_{\mathrm{t}}^{\mathrm{oil}}- \\
& \sum_{\mathrm{j}=0}^{3} \gamma_{\mathrm{j}} \Delta \mathrm{NEER}_{\mathrm{it}-\mathrm{j}}-\sum_{\mathrm{k}=0}^{3} \mu_{\mathrm{k}} \Delta \mathrm{NEER}_{\mathrm{it}-\mathrm{k}}^{2}- \\
& \sum_{\mathrm{l}=0}^{3} v_{\mathrm{l}} \Delta \mathrm{NEER}_{\mathrm{it}-\mathrm{l}}^{3}+\varepsilon_{\mathrm{it}}
\end{aligned}
$$

In all other aspects, we maintain the same specification and notation as in our benchmark Equation 1. Consistently with our approach so far, we estimate Equation 5 separately for advanced economies and emerging markets.

Importantly, by using the orthogonal domestic output gap measure we allocate all the impact arising from the correlation of the global and domestic output gap to the global output gap. Hence, the orthogonal 
domestic output gap estimates constitute a lower bound on the underlying "true" domestic output gap impact, as some of the correlation allocated to the global output gap coefficient might reflect a domestic effect. In contrast, in these orthogonal estimates we obtain more of an upper bound for the global output gap effect. In other words, we make it more difficult to find the domestic output gap to be significant in the orthogonalised setup. If, in spite of this setup, the orthogonal domestic output gap continues to be significant, that would be a strong signal for the relevance of domestic factors.

As before we first focus on advanced economies when we estimate Equation 5 with the orthogonal domestic output gap (Table 5). Most importantly, the results remain strikingly similar to the benchmark results with regard to the domestic output gap, which confirms that our benchmark specification was correct, and that the correlation does not materially affect the domestic output gap estimates. Furthermore, the declining pattern for the domestic output gap coefficient remains unchanged.

\begin{tabular}{|c|c|c|c|c|}
\hline \multirow{2}{*}{\multicolumn{5}{|c|}{$\begin{array}{l}\text { Orthogonal domestic and global output gaps for advanced economies } \\
\text { Coefficients using system GMM estimations in Equation } 5\end{array}$}} \\
\hline & & & & \\
\hline & \multicolumn{4}{|c|}{ Dependent variable: $\pi_{\mathrm{it}}$} \\
\hline & $\begin{array}{c}\text { Whole period } \\
\text { 1994Q1-2017Q4 }\end{array}$ & $\begin{array}{c}\text { Pre-crisis } \\
\text { 1994Q1-2008Q2 }\end{array}$ & $\begin{array}{c}\text { Post-crisis 1 } \\
\text { 2008Q3-2017Q4 }\end{array}$ & $\begin{array}{c}\text { Post-crisis } 2 \\
\text { 2009Q3-2017Q4 }\end{array}$ \\
\hline & (1) & (2) & (3) & (4) \\
\hline \multirow[t]{2}{*}{$\mathrm{y}_{\mathrm{it}}^{d o}$} & $0.0373^{* * *}$ & $0.0560^{* * *}$ & $0.0217^{* *}$ & 0.0100 \\
\hline & $(0.00995)$ & $(0.0140)$ & $(0.01000)$ & $(0.0113)$ \\
\hline \multirow[t]{2}{*}{$\mathrm{y}_{\mathrm{t}}^{g}$} & $0.0773^{* * *}$ & $0.0643^{* * *}$ & $0.0762^{* * *}$ & $0.123 * * *$ \\
\hline & $(0.0105)$ & $(0.0126)$ & $(0.0129)$ & $(0.0392)$ \\
\hline \multirow[t]{2}{*}{$E_{t} \pi_{i t+1}$} & 0.0739 & $0.118^{* *}$ & -0.0526 & $-0.0804 *$ \\
\hline & $(0.0452)$ & $(0.0450)$ & $(0.0313)$ & $(0.0418)$ \\
\hline \multirow[t]{2}{*}{$\pi_{\mathrm{it}-1}$} & $0.506 * * *$ & $0.486 * * *$ & $0.480 * * *$ & $0.443 * * *$ \\
\hline & $(0.0468)$ & $(0.0595)$ & $(0.0359)$ & $(0.0427)$ \\
\hline \multirow[t]{2}{*}{$\pi_{\mathrm{t}}^{\text {oil }}$} & $0.0119 * * *$ & $0.0117^{* * *}$ & $0.0108 * * *$ & $0.0129 * * *$ \\
\hline & $(0.000749)$ & $(0.00168)$ & $(0.000764)$ & $(0.00109)$ \\
\hline NEER terms $^{a}$ & Yes & Yes & Yes & Yes \\
\hline Country FE & Yes & Yes & Yes & Yes \\
\hline Number of countries & 26 & 26 & 26 & 26 \\
\hline Number of observations & 2,291 & 1,329 & 962 & 858 \\
\hline Sargan test $\mathrm{t}^{\mathrm{b}}$ & 1 & 0.998 & 0.887 & 0.261 \\
\hline Hansen test ${ }^{\mathrm{b}}$ & 1 & 1 & 1 & 1 \\
\hline Serial correlation test ${ }^{\mathrm{d}}$ & 0.156 & 0.185 & 0.151 & 0.0458 \\
\hline
\end{tabular}

However, two changes arise for the global output gap coefficient estimates. First, the pre-crisis global output gap estimates become statistically significant in the orthogonal setup. Second, the magnitude 
of the global output gap coefficients becomes larger. Both changes are consistent with obtaining an upper bound estimate for the global output gap effect. Using the orthogonalised domestic output gap, the coefficient on the global output gap is roughly of the same magnitude as that on the domestic output gap in the pre-crisis period, but it becomes significantly larger (more than three times as large) in the post-crisis period.

Next, we repeat the orthogonal analysis for emerging markets (Table 6). The comparison with the benchmark regression shows an even more similar pattern than what we have seen earlier for advanced economies. The coefficients on the orthogonal domestic output gap and global output gap exhibit the same sign and significance and very similar magnitudes as in the benchmark model. Of course, as we expect based on obtaining the upper bound estimates, we find slightly larger and more significant coefficient estimates for the global output gap. This confirms that even in the case of emerging markets, our benchmark regression was well-specified and the correlation does not materially affect the domestic output gap estimates.

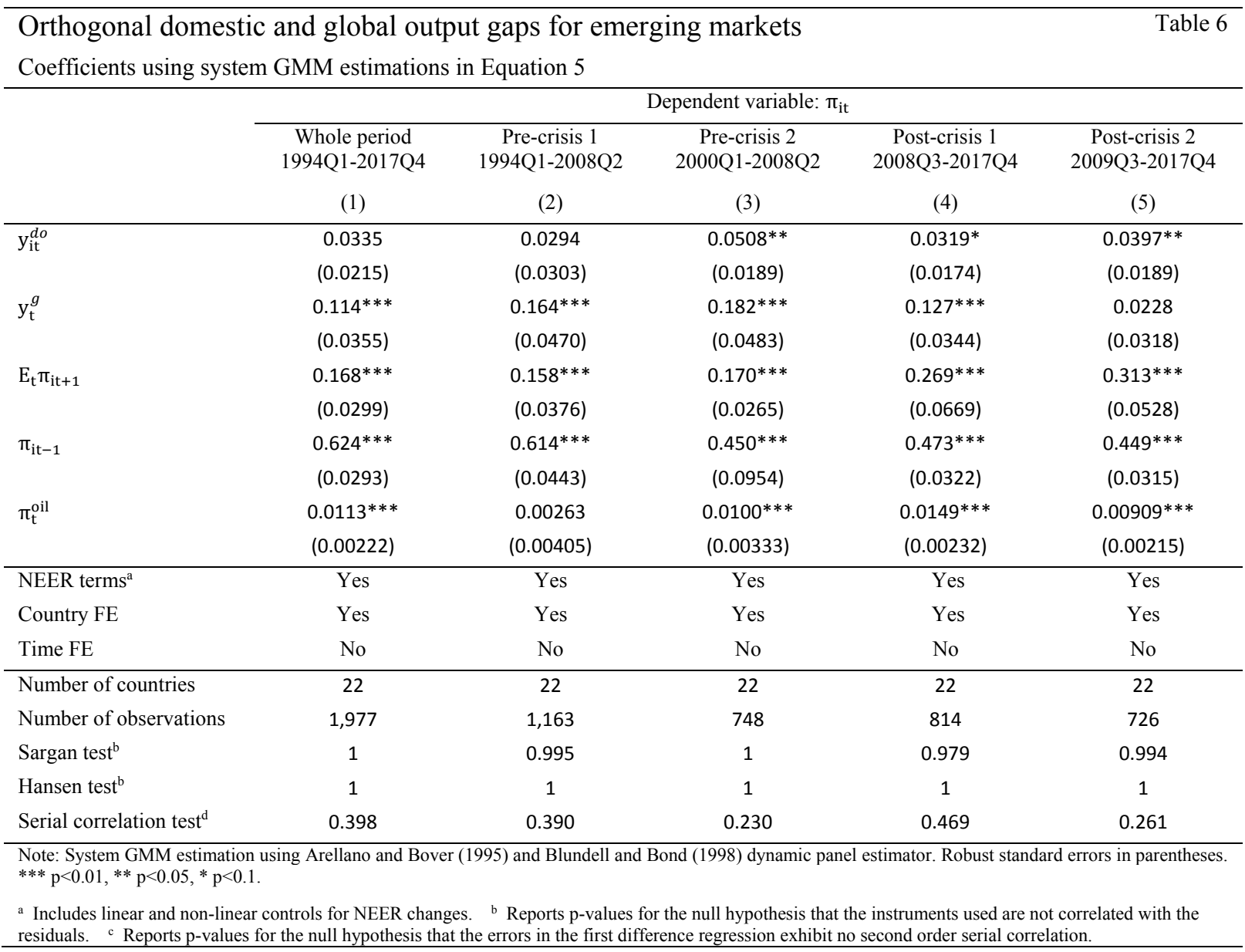


In sum, repeating our analysis of the benchmark regression when using the orthogonal domestic output gaps produces very similar results. While the coefficient estimates for the global output gap become slightly more significant and larger (as expected by removing the correlated parts from the domestic output gap), the orthogonal domestic output gap coefficients remain strikingly similar to the benchmark specification's domestic output gap coefficients. All of the identified main trends, both the declining domestic output gap coefficients in advanced economies and the declining global output gap coefficients in emerging markets, remain robust. All in all, the analysis suggests that our benchmark results are not materially driven by the correlation between the global and domestic output gaps.

\section{Robustness checks}

We check the robustness of our benchmark results to three main changes. First, we check robustness of the results when re-running Equation 1 using a within group specification, instead of the benchmark system GMM specification. Second, we apply time fixed effects to capture all potential effects of globalisation (in addition to global output gaps) when assessing the domestic output gap estimates. Third, we show that our results are also robust when using the global output gap estimated at the World Bank by Kose et al. (2018).

First, we re-estimate Equation 1 using a within-group fixed effect panel regression instead of the benchmark GMM specification. The within group estimate addresses the concern that our sample might not be sufficiently large for the computationally intensive benchmark GMM specification. While the within-group estimates are not perfect, in particular since they give rise to the Nickell (1981) bias and underestimate the persistence parameter (the coefficient on lagged inflation in our case), their small sample properties might be better than the GMM estimates.

Table 7 summarizes the within-group estimates for advanced economies. Broadly speaking, the estimates for both the global and local output gaps confirm the benchmark GMM estimates. Of course, as we expect, the coefficients on the contemporaneous variables (such as the output gaps) tend to be slightly larger, while the estimated inflation persistence (the coefficient on the lagged inflation term) tends 
to be slightly smaller. ${ }^{10}$ Overall, the within group results are consistent with the hypothesis that the GMM specification is appropriate for our sample.

\begin{tabular}{|c|c|c|c|c|}
\hline \multirow{2}{*}{\multicolumn{5}{|c|}{$\begin{array}{l}\text { Effect of domestic and global output gaps for advanced economies } \\
\text { Coefficients using system Within Group estimations in Equation } 1\end{array}$}} \\
\hline & & & & \\
\hline & \multicolumn{4}{|c|}{ Dependent variable: $\pi_{i t}$} \\
\hline & $\begin{array}{c}\text { Whole period } \\
\text { 1994Q1-2017Q4 }\end{array}$ & $\begin{array}{c}\text { Pre-crisis } \\
\text { 1994Q1-2008Q2 }\end{array}$ & $\begin{array}{c}\text { Post-crisis } 1 \\
\text { 2008Q3-2017Q4 }\end{array}$ & $\begin{array}{c}\text { Post-crisis 2 } \\
\text { 2009Q3-2017Q4 }\end{array}$ \\
\hline & (1) & (2) & (3) & (4) \\
\hline \multirow[t]{2}{*}{$\mathrm{y}_{\mathrm{it}}^{d}$} & $0.0433^{* * *}$ & $0.0687^{* * *}$ & $0.0266^{* *}$ & 0.00665 \\
\hline & $(0.0110)$ & $(0.0160)$ & $(0.0110)$ & $(0.0113)$ \\
\hline \multirow[t]{2}{*}{$\mathrm{y}_{\mathrm{t}}^{g}$} & $0.0410^{* *}$ & 0.00451 & $0.0635^{* *}$ & 0.0454 \\
\hline & $(0.0155)$ & (0.0192) & $(0.0273)$ & $(0.0384)$ \\
\hline \multirow[t]{2}{*}{$E_{t} \pi_{i t+1}$} & -0.00226 & -0.0657 & $-0.122 * * *$ & $-0.135 * * *$ \\
\hline & $(0.0471)$ & $(0.0552)$ & $(0.0270)$ & $(0.0326)$ \\
\hline \multirow[t]{2}{*}{$\pi_{\mathrm{it}-1}$} & $0.452 * * *$ & $0.331 * * *$ & $0.431 * * *$ & $0.416^{* * *}$ \\
\hline & $(0.0498)$ & $(0.0690)$ & $(0.0355)$ & $(0.0342)$ \\
\hline \multirow[t]{2}{*}{$\pi_{t}^{\text {oil }}$} & $0.0119 * * *$ & $0.0104^{* * *}$ & $0.0109 * * *$ & $0.0140^{* * *}$ \\
\hline & $(0.000762)$ & $(0.00145)$ & $(0.000816)$ & $(0.00114)$ \\
\hline NEER terms ${ }^{a}$ & Yes & Yes & Yes & Yes \\
\hline Country FE & Yes & Yes & Yes & Yes \\
\hline Number of countries & 26 & 26 & 26 & 26 \\
\hline Number of observations & 2,291 & 1,329 & 962 & 858 \\
\hline R-squared & 0.413 & 0.302 & 0.407 & 0.424 \\
\hline \multicolumn{5}{|c|}{$\begin{array}{l}\text { Note: System GMM estimation using Arellano and Bover (1995) and Blundell and Bond (1998) dynamic panel estimator. Robust standard errors in parentheses. } \\
{ }^{* * *} \mathrm{p}<0.01,{ }^{*} \mathrm{p}<0.05,{ }^{*} \mathrm{p}<0.1 \text {. }\end{array}$} \\
\hline \multicolumn{5}{|c|}{ a Includes linear and non-linear controls for NEER changes. } \\
\hline
\end{tabular}

However, one change arises compared to the benchmark estimates: the effect of the global output gap estimate becomes insignificant when estimated for the post-crisis period excluding the crisis quarters (2009Q3-2017Q4). While this is relevant to note, the decline in significance is primarily driven by the increasing standard errors hence, it might more reflect the specifics of the within group estimate than suggesting an insignificance of the global output gap estimate.

The within-group estimates for emerging economies show a similar pattern to what we have seen previously for the benchmark GMM specification (Table 8). In most time periods, the qualitative results, ie the basic signs and significance levels for the output gap coefficients are the same for the within group and GMM estimates (the exception is that the domestic output gap loses significance in the shorter preand post-crisis periods). Again, the within group estimate of inflation persistence (the coefficient on the lagged inflation term) is slightly

10 Also, the marginally significant inflation expectation terms of Table 1 become significant and negative in the post-crisis estimates. This does not reflect qualitative change: the within group estimate is likely to overestimate the effect of contemporaneous parameters (such as the inflation expectation) while underestimating the persistence parameter. 
smaller. The results again confirm robustness of the benchmark results and suggest that the GMM specification performs generally well for emerging markets as well.

\begin{tabular}{|c|c|c|c|c|c|}
\hline \multirow{2}{*}{\multicolumn{6}{|c|}{$\begin{array}{l}\text { Effect of domestic and global output gaps for emerging markets } \\
\text { Coefficients using system Within Group estimations in Equation } 1\end{array}$}} \\
\hline & & & & & \\
\hline & \multicolumn{5}{|c|}{ Dependent variable: $\pi_{\text {it }}$} \\
\hline & $\begin{array}{c}\text { Whole period } \\
\text { 1994Q1-2017Q4 }\end{array}$ & $\begin{array}{c}\text { Pre-crisis 1 } \\
\text { 1994Q1-2008Q2 }\end{array}$ & $\begin{array}{c}\text { Pre-crisis 2 } \\
\text { 2000Q1-2008Q2 }\end{array}$ & $\begin{array}{c}\text { Post-crisis 1 } \\
\text { 2008Q3-2017Q4 }\end{array}$ & $\begin{array}{c}\text { Post-crisis 2 } \\
\text { 2009Q3-2017Q4 }\end{array}$ \\
\hline & (1) & (2) & (3) & (4) & (5) \\
\hline \multirow[t]{2}{*}{$\mathrm{y}_{\mathrm{it}}^{d}$} & 0.0319 & 0.0217 & 0.0169 & $0.0472 * *$ & 0.0271 \\
\hline & $(0.0226)$ & $(0.0273)$ & $(0.0246)$ & $(0.0180)$ & $(0.0217)$ \\
\hline \multirow[t]{2}{*}{$\mathrm{y}_{\mathrm{t}}^{g}$} & $0.0772 * *$ & $0.131^{* * *}$ & $0.187^{* * *}$ & $0.0881^{* *}$ & -0.0459 \\
\hline & $(0.0358)$ & $(0.0417)$ & $(0.0618)$ & $(0.0388)$ & $(0.0432)$ \\
\hline \multirow[t]{2}{*}{$E_{t} \pi_{i t+1}$} & $0.155^{* * *}$ & $0.131 * *$ & $0.0663^{*}$ & 0.0719 & 0.131 \\
\hline & $(0.0356)$ & $(0.0545)$ & $(0.0341)$ & $(0.113)$ & (0.101) \\
\hline \multirow[t]{2}{*}{$\pi_{i t-1}$} & $0.602 * * *$ & $0.569 * * *$ & $0.269 * * *$ & $0.349 * * *$ & $0.328^{* * *}$ \\
\hline & $(0.0299)$ & $(0.0510)$ & $(0.0936)$ & $(0.0469)$ & $(0.0549)$ \\
\hline \multirow[t]{2}{*}{$\pi_{\mathrm{t}}^{\text {oil }}$} & $0.0111^{* * *}$ & 0.00164 & $0.0103^{* * *}$ & $0.0134^{* * *}$ & $0.00902 * * *$ \\
\hline & $(0.00217)$ & $(0.00428)$ & $(0.00326)$ & $(0.00229)$ & $(0.00225)$ \\
\hline NEER terms $^{a}$ & Yes & Yes & Yes & Yes & Yes \\
\hline Country FE & Yes & Yes & Yes & Yes & Yes \\
\hline Number of countries & 22 & 22 & 22 & 22 & 22 \\
\hline Number of observations & 1,977 & 1,163 & 748 & 814 & 726 \\
\hline R-squared & 0.775 & 0.764 & 0.629 & 0.493 & 0.522 \\
\hline
\end{tabular}

Second, we address the concern that unobserved global factors might affect our benchmark results. While our benchmark specification controls for the global output gap and oil prices, which are in our view the two most important global factors, it does not formally include other potentially relevant drivers of globalisation, such as the emergence of cross-border supply chains and increasing trade openness. In order to control for all of these potential other global factors, we repeat our benchmark regression with applying time (quarter) fixed effects (and naturally drop the global output gap and the oil price variables). Formally, we estimate a slightly modified version of Equation 1 as shown in Equation 6:

$$
\begin{aligned}
\pi_{\mathrm{it}}= & \alpha_{\mathrm{i}}+\lambda_{\mathrm{t}}+\rho \mathrm{E}_{\mathrm{t}} \pi_{\mathrm{it}+1}+\delta \pi_{\mathrm{it}-1}+\phi \mathrm{y}_{\mathrm{it}}^{d}-\sum_{\mathrm{j}=0}^{3} \gamma_{\mathrm{j}} \Delta \mathrm{NEER}_{\mathrm{it}-\mathrm{j}}- \\
& \sum_{\mathrm{k}=0}^{3} \mu_{\mathrm{k}} \Delta \mathrm{NEER}_{\mathrm{it}-\mathrm{k}}^{2}-\sum_{\mathrm{l}=0}^{3} \nu_{\mathrm{l}} \Delta \mathrm{NEER}_{\mathrm{it}-\mathrm{l}}^{3}+ \\
& \varepsilon_{\mathrm{it}}
\end{aligned}
$$

where $\lambda_{t}$ denotes the time (quarter) fixed effects. 
In the case of both advanced economies and emerging markets, the time fixed effect regression results are very similar to the benchmark regression results (see Tables B1 and B2 in the Appendix, respectively). Importantly, this is not only the case for the domestic output gap coefficient, but also for the inflation persistence and inflation expectation coefficients. This confirms that in the case of advanced economies, unobserved global factors do not materially affect our estimates of the coefficient on the domestic output gap.

Next, we address the concern about the measurement of the global output gap. In our benchmark regression we calculated the global output gap measure using PPP-based GDP weights of individual country output gaps (consistent with the BIS methodology). In an alternative setup, we re-estimate our benchmark regression using the global output gap measure from Kose et al. (2018) at the World Bank, to ensure that our results do not depend on a particular global output gap measure. The regression results, which follow our benchmark regression results for advanced economies (Table 1 ) and emerging markets (Table 2) are shown in Appendix Tables B3 and B4, respectively. The coefficient estimates are very close to our benchmark estimates for all time periods, both for advanced and emerging economies, confirming that our results are not materially driven by the choice of global output gap estimate.

\section{Conclusions}

We studied how domestic and global output gaps affect CPI inflation using a New-Keynesian Phillips curve framework, for a panel of 26 advanced and 22 emerging economies from 1994 to 2017. We controlled for non-linearities in exchange rate pass-through when estimating the effects of output gaps, as well as for the effects of oil prices.

We find broadly two different trends for advanced economies and emerging markets. While in advanced economies the effect of the domestic output gap declines significantly after the crisis, in emerging markets the effect of the global output gap declines significantly after the crisis. These results hold robustly under extensive changes in specification. Conversely, we find some signs that the effect of the global output gap remains stable in advanced economies, and the effect of the domestic output gap remains stable in emerging markets, but these two latter results are less robust to different specifications. Most importantly, the paper highlights the usefulness of the New- 
Keynesian Phillips curve framework to analyse the relative role of domestic and global factors, particularly of domestic and global output gaps, as inflation drivers.

The results offer direct policy implications. On the one hand, they contribute evidence on the flattening Phillips curve for advanced economies. While the results should not be seen as applying to any individual country, but rather to a group of countries, they still suggest that advanced economy central banks and international organisations were right to discuss policy options when inflation becomes less responsive to domestic factors. On the other hand, the results also highlight that the trends for emerging markets differ. Hence, emerging market central banks and policy makers should carefully evaluate advanced economy focussed arguments when formulating their policies.

In addition, the results also offer an insight into the drivers of inflation during the post-crisis recovery, and why inflation remained weak afterwards. To shed light on this question we estimate how much the output gap responses of our model explain of inflation during (i) the post-crisis recovery (2009 Q2-2011 Q3) and (ii) the recent low inflation period (2011-2017).

Our model suggests that the domestic and global output gaps in advanced economies contributed to higher inflation during the postcrisis recovery (2009 Q2 - 2011 Q3). Inflation increased 54 basis points on average, and our model suggests that the output gaps implied roughly on average an increase in inflation of around 23 basis points using short-run coefficients, and 44 basis points using long-run coefficients as both domestic and global output gaps increased strongly (by more than three percentage point each).

However, other factors than the output gaps seem to be responsible for the weak observed inflation during the 2011-2017 period. Inflation fell on average by more than 40 basis points in advanced economies, partly driven by oil prices, while the output gaps suggest a very small increase in inflation of below 1 basis point as the output gaps moved in the opposite direction: the effect of moderate increase of the average domestic output gaps (around 60 basis points) was largely offset by the effects of the decline in the global output gap (around 20 basis points).

We conclude that the New-Keynesian Phillips curve framework continues to be useful for estimating the effects of output gaps on inflation in a cross-country setting. It is well-suited to control for non- 
linear exchange rate pass-through and also for potential unobserved global factors in a framework relevant for monetary policy. 


\section{References}

Arellano, M. and O. Bover (1995) "Another Look at the Instrumental Variable Estimation of Error-Components Models," Journal of Econometrics 68, 29-51.

Auer, Raphael, Claudio Borio and Andrew Filardo. (2017). "The Globalisation of Inflation: the Growing Importance of Global Value Chains." Bank for International Settlements Working Paper No. 602.

Ball, Laurence. (2006). "Has Globalization Changed Inflation?" NBER Working Paper 12687. November.

Ball, L. and S. Mazumder (2011), "Inflation Dynamics and the Great Recession," Brookings Papers on Economic Activity (Spring), 337-381.

Bean, Charles. (2006). "Globalisation and Inflation." Bank of England Quarterly Bulletin Q4, pgs. 468-475.

Berganza, Juan Carlos, Petro del Rio and Fructuoso Borrallo. (2016). "Determinants and Implications of Low Global Inflation Rates." Banco de Espana Documentos Ocasionales No. 1608.

Blanchard, Olivier (2016), "The Phillips Curve: Back to the '60s?" American Economic Review, 106 (5): 31-34.

Blanchard, Olivier, Eugenio Cerutti and Lawrence Summers (2015). "Inflation and Activity: Two Explorations and their Monetary Policy Implications", IMF Working Paper No. WP/15/230.

Blundell, R. and S. Bond (1998) "Initial Conditions and Moment Restrictions in Dynamic Panel Data Models," Journal of Econometrics 87, 115-143.

Borio, Claudio and Andrew Filardo. (2007). "Globalisation and Inflation: New Cross-country Evidence on the Global Determinants of Domestic Inflation." BIS Working Papers No 227.

Bussière, M. (2013). "Exchange Rate Pass-Through to Trade Prices: The Role of Nonlinearities and Asymmetries". Oxford Bulletin of Economics and Statistics, Vol. 75 (5), 731-758.

Cheikh, N. and C. Rault (2015), "The Pass-Through of Exchange Rate in the Context of the European Sovereign Debt Crisis", CESifo Working Paper No. 5550.

Ciccarelli, Matteo and Benoit Mojon. (2010). "Global Inflation." The Review of Economics and Statistics 92(3): 524-535.

Cunliffe, J. (2017), "The Phillips curve: lower, flatter or in hiding?", speech given at the Oxford Economics Society, 14 November. 
Eickmeier, Sandra and Katharina Pijnenburg. (2013). "The Global Dimension of Inflation - Evidence from Factor-augmented Phillips Curves." Oxford Bulletin of Economics and Statistics 75(1): 103-122.

Gamber, Edward and Juann Hung. (2001). "Has the Rise in Globalization Reduced U.S. Inflation in the 1990s?" Economic Inquiry 39(1): 58-73.

Forbes, K. (2018). "Has Globalization Changed the Inflation Process?" MIT-Sloan School of Management, manuscript, June.

Gordon, Robert. (2013). "The Phillips Curve is Alive and Well: Inflation and the NAIRU during the Slow Recovery." NBER Working Paper 19390.

Ihrig, Jane, Steven Kamin, Deborah Lindner and Jaime Marquez. (2010). "Some Simple Tests of the Globalization and Inflation Hypothesis." International Finance 13(3): 343-375.

IMF (2013), "The dog that didn't bark: has inflation been muzzled or was it just sleeping?", World Economic Outlook, April, Chapter 3.

Jašová, M., Moessner, R. and Takáts, E. (2018). "Exchange rate passthrough: What has changed since the crisis?", International Journal of Central Banking, forthcoming.

Kiley, Michael (2015), "Low Inflation in the United States: A Summary of Recent Research.", FEDS Notes, Board of Governors of the Federal Reserve System.

Kohn, D. (2005), "Inflation Modeling: A Policymaker's Perspective," speech given at Quantitative Evidence on Price Determination Conference, Washington, D.C., 29 September.

Kose, A., Ohnsorge, F. and M. Some (2018), "Is the global economy turning the corner?", World Bank, Global Economic Prospects, January, Chapter I, Box 1.1, p. 8-12.

Kuttner, K. and T. Robinson (2010), "Understanding the flattening Phillips curve", North American Journal of Economics and Finance, 21, 110-125.

Mikolajun, Irena and David Lodge. (2016). "Advanced Economy Inflation: The Role of Global Factors." ECB Working Paper No 1948.Nickell, Steven (1981) "Biases in Dynamic Models with Fixed Effects", Econometrica, 1981, vol. 49, issue 6, 1417-26

Mojon, B. and X. Ragot (2018), "The labor supply of baby-boomers and low-flation", Sciences Po OFCE Working Paper No. 09, 2018/01.

Reichlin, L. (2018), Discussion of 'Slack and Cyclically Sensitive Inflation by J. Stock and M. Watson', ECB Annual Forum, Sintra, 18 - 20 June; 
https://www.ecb.europa.eu/pub/conferences/shared/pdf/20180618_e cb_forum_on_central_banking/Reichlin_Lucrezia_Presentation.pdf .

Roberts, J. (2006), "Monetary policy and inflation dynamics", International Journal of Central Banking, 2(3), 193-230. 


\section{Appendix A}

Data sources

Table A1

\begin{tabular}{|c|c|c|}
\hline Variable & Description & Source \\
\hline \multicolumn{3}{|l|}{ Inflation } \\
\hline Consumer price index & Quarter-on-quarter log changes, seasonally adjusted. & $\begin{array}{l}\text { Datastream } \\
\text { National data } \\
\text { BIS }\end{array}$ \\
\hline \multicolumn{3}{|l|}{ Inflation expectations } \\
\hline Inflation expectations & $\begin{array}{l}\text { Quarter-on-quarter inflation expectations. } \\
\text { Data are derived from yearly Consensus surveys' inflation } \\
\text { expectations by assuming constant inflation over the coming } \\
\text { quarters within the year. }\end{array}$ & $\begin{array}{l}\text { Consensus Economics } \\
\text { Datastream } \\
\text { National data } \\
\text { BIS } \\
\text { Authors' calculations }\end{array}$ \\
\hline \multicolumn{3}{|l|}{ Output gaps } \\
\hline Domestic output gap & $\begin{array}{l}\text { Standard Hodrick-Prescott filter applied on quarterly real GDP } \\
\text { series. } \\
\text { GDP in levels; domestic currency units. }\end{array}$ & $\begin{array}{l}\text { National data } \\
\text { BIS } \\
\text { Authors' calculations }\end{array}$ \\
\hline \multirow[t]{2}{*}{ Global output gap } & $\begin{array}{l}\text { Standard Hodrick-Prescott filter applied on quarterly real GDP } \\
\text { series. }\end{array}$ & $\begin{array}{l}\text { National data } \\
\text { BIS } \\
\text { Authors' calculations }\end{array}$ \\
\hline & $\begin{array}{l}\text { National output gaps of each country are estimated using nine } \\
\text { different methods (including univariate and multivariate filters, } \\
\text { the production function approach and two expectations-based } \\
\text { measures), and are then aggregated into a global output gap using } \\
\text { GDP weights. } \\
\text { Sample includes } 15 \text { advanced economies and } 23 \text { emerging } \\
\text { market and developing economies; quarterly data for } 2000-17 \text {. }\end{array}$ & $\begin{array}{l}\text { Kose, Ohnsorge and } \\
\text { Some (2018) }\end{array}$ \\
\hline \multicolumn{3}{|c|}{ 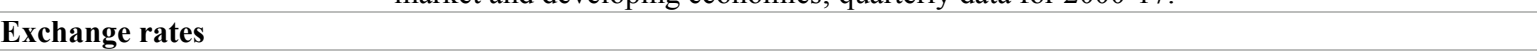 } \\
\hline $\begin{array}{l}\text { Nominal effective exchange } \\
\text { rate }\end{array}$ & $\begin{array}{l}\text { Nominal effective exchange rate indices are calculated as } \\
\text { geometric weighted averages of bilateral exchange rates. Broad } \\
\text { indices comprise of } 61 \text { economies, with data from } 1994 . \\
\text { Quarterly averages, quarter-on-quarter log changes. }\end{array}$ & BIS \\
\hline \multicolumn{3}{|c|}{ Q } \\
\hline Oil prices & $\begin{array}{l}\text { West Texas Intermediate (WTI) crude oil spot price. } \\
\text { Quarterly averages, quarter-on-quarter log changes. }\end{array}$ & Bloomberg \\
\hline
\end{tabular}




\section{Appendix tables}

Effect of domestic output gap for advanced economies, with time fixed effects

Table B1 Coefficients using system GMM estimations in Equation 6

\begin{tabular}{|c|c|c|c|c|}
\hline & & Depend & able: $\pi_{\text {it }}$ & \\
\hline & $\begin{array}{c}\text { Whole period } \\
\text { 1994Q1-2017Q4 }\end{array}$ & $\begin{array}{c}\text { Pre-crisis } \\
\text { 1994Q1-2008Q2 }\end{array}$ & $\begin{array}{c}\text { Post-crisis 1 } \\
\text { 2008Q3-2017Q4 }\end{array}$ & $\begin{array}{c}\text { Post-crisis 2 } \\
\text { 2009Q3-2017Q4 }\end{array}$ \\
\hline & (1) & (2) & (3) & (4) \\
\hline $\mathrm{y}_{\mathrm{it}}^{d}$ & $0.0366^{* * *}$ & $0.0532 * * *$ & $0.0252^{* *}$ & 0.0165 \\
\hline & $(0.0112)$ & $(0.0151)$ & $(0.0108)$ & $(0.0118)$ \\
\hline$E_{t} \pi_{i t+1}$ & 0.0580 & $0.0981 * *$ & -0.0561 & -0.0771 \\
\hline & $(0.0432)$ & $(0.0435)$ & $(0.0338)$ & $(0.0496)$ \\
\hline$\pi_{\mathrm{it}-1}$ & $0.511 * * *$ & $0.532^{* * *}$ & $0.428^{* * *}$ & $0.365^{* * *}$ \\
\hline & $(0.0536)$ & $(0.0652)$ & $(0.0438)$ & $(0.0570)$ \\
\hline NEER terms ${ }^{\mathrm{a}}$ & Yes & Yes & Yes & Yes \\
\hline Country FE & Yes & Yes & Yes & Yes \\
\hline Time FE & Yes & Yes & Yes & Yes \\
\hline Number of countries & 26 & 26 & 26 & 26 \\
\hline Number of observations & 2,291 & 1,329 & 962 & 858 \\
\hline Sargan test ${ }^{\mathrm{b}}$ & 0.999 & 0.988 & 0.0976 & 0.000436 \\
\hline Hansen test ${ }^{\mathrm{b}}$ & 1 & 1 & 1 & 1 \\
\hline Serial correlation test $\mathrm{d}^{\mathrm{d}}$ & 0.105 & 0.0958 & 0.225 & 0.0250 \\
\hline $\begin{array}{l}\text { Note: System GMM estima } \\
* * * \mathrm{p}<0.01, * * \mathrm{p}<0.05, * \mathrm{p}\end{array}$ & and Bover (1995) & ell and Bond (1998) & panel estimator. Rob & ird errors in parentl \\
\hline
\end{tabular}

Effect of domestic output gap for EMEs, with time fixed effects Table B2

Coefficients using system GMM estimations in Equation 6

\begin{tabular}{|c|c|c|c|c|c|}
\hline & \multicolumn{5}{|c|}{ Dependent variable: $\pi_{i t}$} \\
\hline & $\begin{array}{c}\text { Whole period } \\
\text { 1994Q1-2017Q4 }\end{array}$ & $\begin{array}{c}\text { Pre-crisis 1 } \\
\text { 1994Q1-2008Q2 }\end{array}$ & $\begin{array}{c}\text { Pre-crisis } 2 \\
\text { 2000Q1-2008Q2 }\end{array}$ & $\begin{array}{c}\text { Post-crisis 1 } \\
\text { 2008Q3-2017Q4 }\end{array}$ & $\begin{array}{c}\text { Post-crisis } 2 \\
\text { 2009Q3-2017Q4 }\end{array}$ \\
\hline & (1) & (2) & (3) & (4) & (5) \\
\hline \multirow[t]{2}{*}{$\mathrm{y}_{\text {it }}^{d}$} & 0.0247 & 0.0199 & $0.0490 * *$ & $0.0347^{* *}$ & $0.0433 * *$ \\
\hline & $(0.0167)$ & $(0.0243)$ & $(0.0231)$ & $(0.0165)$ & $(0.0170)$ \\
\hline \multirow[t]{2}{*}{$E_{t} \pi_{i t+1}$} & $0.161 * * *$ & $0.151 * * *$ & $0.180 * * *$ & $0.267 * * *$ & $0.319 * * *$ \\
\hline & $(0.0316)$ & $(0.0412)$ & $(0.0269)$ & $(0.0706)$ & $(0.0590)$ \\
\hline \multirow[t]{2}{*}{$\pi_{\mathrm{it}-1}$} & $0.614^{* * *}$ & $0.606 * * *$ & $0.444 * * *$ & $0.472 * * *$ & $0.431 * * *$ \\
\hline & $(0.0332)$ & $(0.0464)$ & $(0.0973)$ & $(0.0378)$ & (0.0359) \\
\hline NEER terms $^{\mathrm{a}}$ & Yes & Yes & Yes & Yes & Yes \\
\hline Country FE & Yes & Yes & Yes & Yes & Yes \\
\hline Time FE & Yes & Yes & Yes & Yes & Yes \\
\hline Number of countries & 22 & 22 & 22 & 22 & 22 \\
\hline Number of observations & 1,977 & 1,163 & 748 & 814 & 726 \\
\hline Sargan test ${ }^{\mathrm{b}}$ & 0.991 & 0.737 & 0.894 & 0.321 & 0.311 \\
\hline Hansen test ${ }^{\mathrm{b}}$ & 1 & 1 & 1 & 1 & 1 \\
\hline Serial correlation test ${ }^{\mathrm{d}}$ & 0.381 & 0.356 & 0.207 & 0.810 & 0.305 \\
\hline
\end{tabular}


Coefficients using system GMM estimations in Equation 1, for global output gap estimate of Kose et al. (2018)

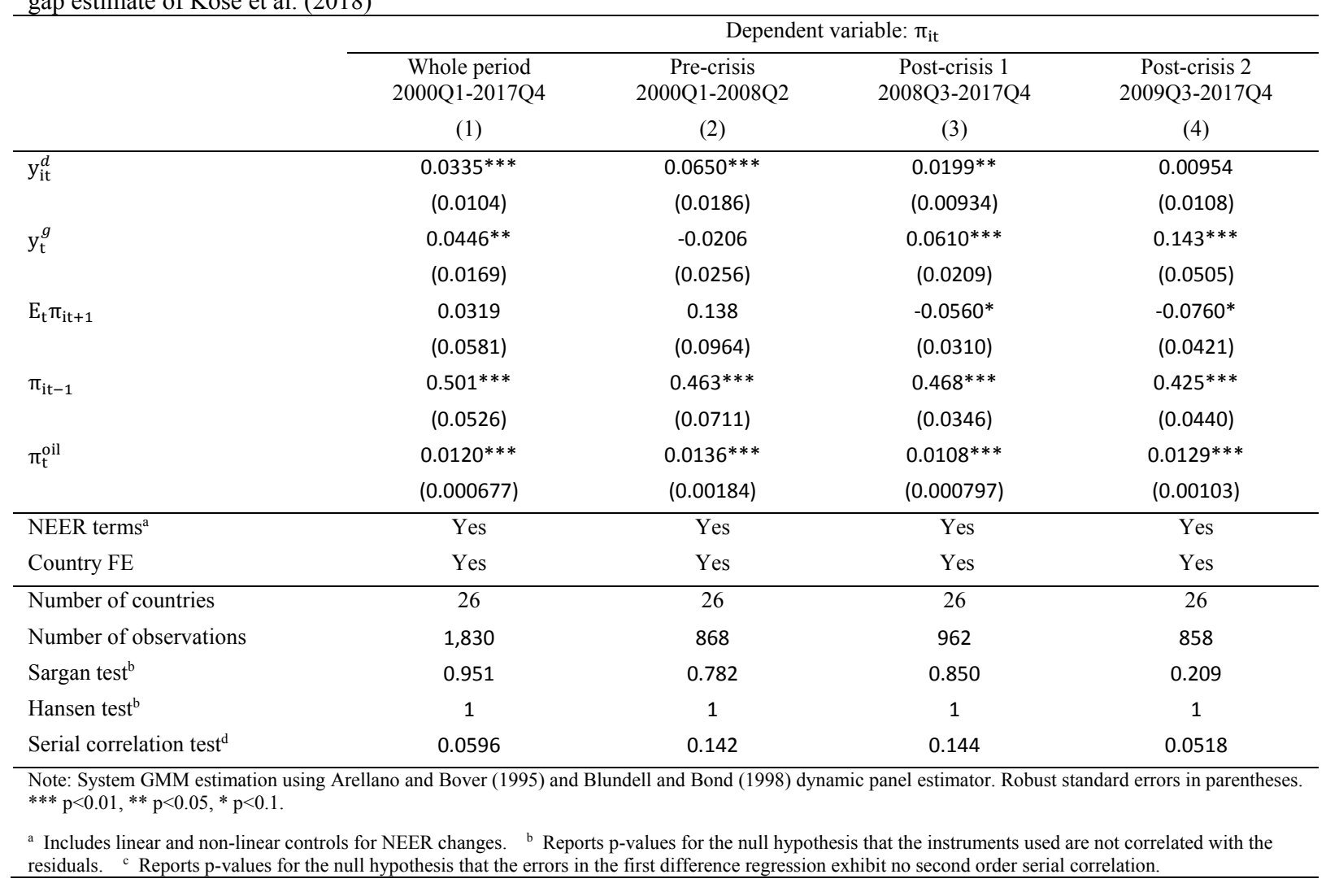


Effect of domestic and global output gaps for EMEs

Coefficients using system GMM estimations in Equation 1, for global output gap estimate of Kose et al. (2018)

\begin{tabular}{|c|c|c|c|c|}
\hline & \multicolumn{4}{|c|}{ Dependent variable: $\pi_{i t}$} \\
\hline & $\begin{array}{c}\text { Whole period } \\
\text { 2000Q1-2017Q4 }\end{array}$ & $\begin{array}{c}\text { Pre-crisis } \\
\text { 2000Q1-2008Q2 }\end{array}$ & $\begin{array}{c}\text { Post-crisis 1 } \\
\text { 2008Q3-2017Q4 }\end{array}$ & $\begin{array}{c}\text { Post-crisis } 2 \\
\text { 2009Q3-2017Q4 }\end{array}$ \\
\hline & (1) & (2) & (3) & (4) \\
\hline \multirow[t]{2}{*}{$\mathrm{y}_{\mathrm{it}}^{d}$} & $0.0387^{*}$ & $0.0513^{* *}$ & $0.0354^{*}$ & $0.0352^{*}$ \\
\hline & $(0.0194)$ & $(0.0204)$ & $(0.0181)$ & (0.0193) \\
\hline \multirow[t]{2}{*}{$\mathrm{y}_{\mathrm{t}}^{g}$} & 0.0889 & $0.110 * *$ & $0.0818^{*}$ & -0.00706 \\
\hline & $(0.0549)$ & $(0.0420)$ & $(0.0451)$ & $(0.0414)$ \\
\hline \multirow[t]{2}{*}{$E_{t} \pi_{i t+1}$} & $0.200 * * *$ & $0.165^{* * *}$ & $0.269 * * *$ & $0.314 * * *$ \\
\hline & $(0.0277)$ & $(0.0280)$ & $(0.0674)$ & $(0.0524)$ \\
\hline \multirow[t]{2}{*}{$\pi_{\mathrm{it}-1}$} & $0.464^{* * *}$ & $0.418^{* * *}$ & $0.471^{* * *}$ & $0.448 * * *$ \\
\hline & $(0.0691)$ & $(0.118)$ & $(0.0340)$ & $(0.0321)$ \\
\hline \multirow[t]{2}{*}{$\pi_{\mathrm{t}}^{\mathrm{oil}}$} & $0.0132 * * *$ & $0.0106 * * *$ & $0.0150 * * *$ & $0.00935^{* * *}$ \\
\hline & $(0.00203)$ & $(0.00355)$ & $(0.00231)$ & $(0.00207)$ \\
\hline NEER terms $^{\mathrm{a}}$ & Yes & Yes & Yes & Yes \\
\hline Country FE & Yes & Yes & Yes & Yes \\
\hline Time FE & No & No & No & No \\
\hline Number of countries & 22 & 22 & 22 & 22 \\
\hline Number of observations & 1,562 & 748 & 814 & 726 \\
\hline Sargan test ${ }^{\mathrm{b}}$ & 1 & 1 & 0.972 & 0.994 \\
\hline Hansen test ${ }^{\mathrm{b}}$ & 1 & 1 & 1 & 1 \\
\hline Serial correlation test ${ }^{\mathrm{d}}$ & 0.239 & 0.214 & 0.470 & 0.256 \\
\hline $\begin{array}{l}\text { Note: System GMM estimat } \\
*_{* *} \mathrm{p}<0.01,{ }^{* *} \mathrm{p}<0.05,{ }^{*} \mathrm{p}<\end{array}$ & $\mathrm{o}$ and Bover (1995) & 11 and Bond (1998) & anel estimator. Rob & ard errors in parenthe \\
\hline
\end{tabular}

